\title{
IMPROVING STUDENTS' VOCABULARY MASTERY TROUGH SNOWING BALL IN DESCRIPTIVE TEXT
}

\author{
Nur Azizah ${ }^{1}$, Odo Fadloeli ${ }^{2}$ \\ 1,2 IKIP Siliwangi \\ ${ }^{1}$ nurafaa14@gmail.com, ${ }^{2}$ odofadloeli@gmail.com
}

\begin{abstract}
The objective of this research study was to show how to improve the student's vocabulary through snowing ball. Snowing ball is a way of presenting learning materials where students are formed in several heterogeneous groups to make a vocabulary. The data were obtained by the teaching and learning process, and analyze the student assessment results. The data collected were quantitative. The data analyzed from the control class value and experiment class value. The result of this research was showed the snowing ball method that used on this research will increase the average students' score by $86 \%$. It mean the snowing ball method on the control class is successful to improving the students' vocabulary mastery. It also means the snowing ball method was successful to improve the student's vocabulary.
\end{abstract}

Keywords: Vocabulary, Snowing Ball, Improvement

\section{INTRODUCTION}

In Indonesia, English is the first foreign language which is considered as an important means in absorbing and developing science, technology, art, and culture as well as establishing relationships with other countries. The purpose of teaching English is to fulfill the needs of learning process by considering student's background, school condition and the environment as part of the curriculum role in Indonesia 2013. In the English teaching and learning process, the task of the teachers is not just to import knowledge, but also give the students the necessary aids, experience, and information that will enable them to develop themselves. Such task can be carried out by the teachers by understanding the students' characteristics based on the intellectual growth of each student. Therefore, teachers can make use of media and implement various interesting activities to make the students interested in learning English which later on develop themselves (Brown, 2019). The purpose of this study was to determine the snowing ball's method to improve students' vocabulary mastery using descriptive text of seventh grade at SMP N 5 Pasirkuda.

\section{Student's Vocabulary}

Broadly defined, vocabulary is knowledge of words and word meanings (Beck, McKeown, \& Kucan, 2018). Its is one of the main components in a language, which with no words no language exist. They are the means by which people exchange their thought to each other. The indicates that someone needs to master the words, know the meaning of those words and use them or he can participate in the conversation.

Murcia (2001: 285) as cited in Parmawati (2018) states that vocabulary learning is central to language acquisition, whether the language is first, second, or foreign. Vocabulary affects the communication process (Burns, 2018). It affects the will and the ability to express ideas correctly. Tarigan notes that one's language skill depends on vocabulary mastery. The more 
vocabulary one has, the more chance one has to be able to communicate. Furthermore, one's ideas or thoughts will be better understood if they are expressed in the appropriate and correct words.

In line with Tarigan, Krashen, and Terrel argue that vocabulary is basic to communication (Echevaria, 2018). If learners do not recognize the meanings of the key words used by those who address them, they will be unable to participate in the conversation. And if they wish to express some ideas, opinion, or ask for information, they must be able to produce lexical items to convey their meaning. Krashen and Terrel write that vocabulary is important for the acquisition process and as a base for communication (Haerunisa, 2019). People acquire morphology and syntax because they understand the meaning of utterances. Acquisition depends on the input being comprehensible. And comprehensibility is dependent directly on the ability to recognize their meaning of the key elements in the utterance. Therefore, acquisition will not take place without comprehension of vocabulary.

Vocabulary is needed by people to understand the meaning of words and it helps them to express the ideas precisely (Hughes, 2019). It is a reality that each of the four language skills in the language learning process, which are listening, speaking, reading, and writing, requires the mastery of vocabulary. Limited word mastery will give bad influences in the process of teaching and learing of a language.

\section{Snowing Ball's Method}

Rahman defined that snowball throwing is one of the learning methods, where students are given the opportunity and freedom to build or create knowledge (Rahman, 2018). Creating a knowledge can be done by students trying to give meaning or meaning to the knowledge they have experienced.

\section{METHOD}

This type of research is descriptive quantitative. The research on improving the vocabulary mastery through snowing ball of the grade VII students was an action research, which focused on the efforts to improve students' vocabulary mastery on the English teaching process (Sugiyono, 2016).

The model of control and experimental class designed in learning process on this research as follow:

\begin{tabular}{lll} 
Class & Snowing Ball & Test Result \\
\hline Control Class & $\mathrm{N}_{1}$ \\
Experimental Class & $\longrightarrow \mathrm{N}$
\end{tabular}

\section{Data Analysis}

The data analysis using wilcoxon signed rank's test. The wilcoxon signed rank test is a nonparametric test to measure the significance of the difference between two pairs of ordinal or interval scale data but with an abnormal distribution. Wilcoxon signed rank test is an alternative test from pairing $t$ test or paired $t$ test if it does not meet the assumption of normality. This test is also known as the Wilcoxon Match Pair Test. 
For example the wilcoxon signed rank test usually used for measure the significance of differences in student test score before ant after lessons. So, on this research the researcher would like to analyze the students' score using wilcoxon signed rank's test.

\section{RESULTS AND DISCUSSION}

\section{Results}

The snowing ball method could cover the need for all types of students. The snowing ball give a freedom for students in the experiment class to increase their vocabulary and improving themselves in English. So, we concluded that snowing ball method are more affected to improving students' vocabulary. The use of Classroom English and English routines proved to be helpful in the acquisition of English competencies. The students were familiar with it and began to use it. For the long and complex expressions, although the students did not get the exact meaning, they could comprehend the language.

The combination of English and Indonesian could help the students to understand the teacher's explaation and instruction. It was also helpful when the teacher used gestures so that the students could get the better understanding in the teacher's explanation and instruction. On the data analyze, the researcher using quantitative data analysis method such as comparison chart and the wilcoxon signed ranks test using SPSS version 23. The result of the chart comparison as follow:

Chart 1. Comparison of students' score average

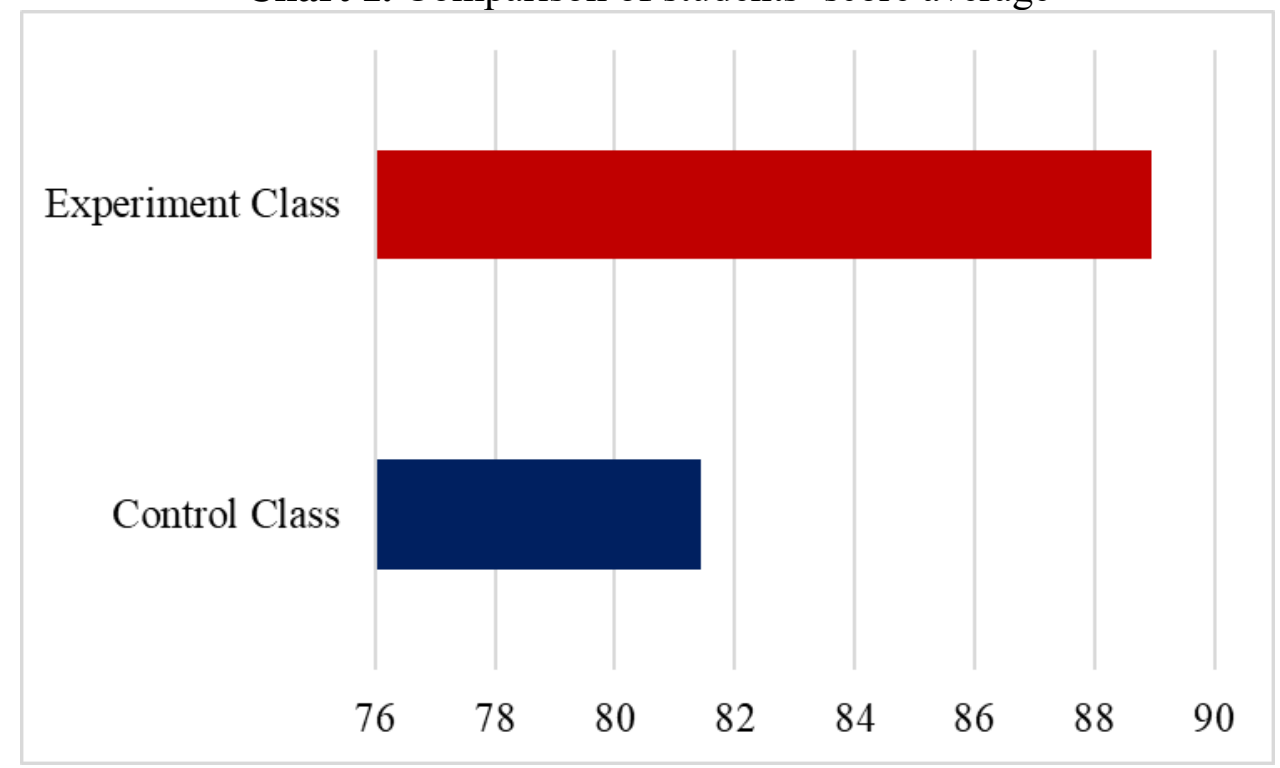

Source : Research Result (2020).

Based on the Chart 1 above about comparison of students' score average we know that the average students in experiment class is higher then average students in control class. It mean the snowing ball's method that used on this research is successful to improve the student's score in English on experiment class and success to improve their vocabolary mastery. To make sure that the result of this study and data showed above. The researcher analyzing data with wilcoxon signed rank's test for founding the comparison between experiment class score and control class score. Before we tested the data using wilcoxon signed rank's test, we should have normality test using Kolmogorov-Smirnov's Test to make sure that data distribution is not normal. 
Table 1. Test of Normality

\begin{tabular}{|ll|r|}
\hline \multicolumn{2}{|c|}{ One-Sample Kolmogorov-Smirnov Test } & \multicolumn{1}{|c|}{ Experiment Class_Score } \\
\hline $\mathrm{N}$ & & 36 \\
Normal Parameters ${ }^{\mathrm{a}, \mathrm{b}}$ & Mean & 88.9444 \\
& Std. Deviation & 3.64844 \\
Most Extreme Differences & Absolute & .275 \\
& Positive & .275 \\
& Negative & -.203 \\
Test Statistic & & .275 \\
Asymp. Sig. (2-tailed) & & $.000^{c}$ \\
\hline
\end{tabular}

c. Lilliefors Significance Correction.

The above table shows that the significance value of data was 0,000 . This value was lower than 0,05 . It means the data was not normally distributed. So, if the data is not normally distributed to find out the comparison between control class and experiment class score we must using wilcoxon signed rank's test for unnormally data distributed.

Table 2. Result of Wilcoxon Signed Rank's Test

\begin{tabular}{|l|r|r|r|}
\hline \multicolumn{1}{|c|}{ Experiment Class Score - Control Class Score } & N & \multicolumn{1}{c|}{$\begin{array}{c}\text { Mean } \\
\text { Rank }\end{array}$} & \multicolumn{1}{c|}{$\begin{array}{c}\text { Sum of } \\
\text { Ranks }\end{array}$} \\
\hline Negative Ranks & $1^{\mathrm{a}}$ & 2.50 & 2.50 \\
Positive Ranks & $31^{\mathrm{b}}$ & 16.95 & 525.50 \\
Ties & $4^{\mathrm{c}}$ & & \\
Total & 36 & & \\
\hline
\end{tabular}

a. Experiment Class_Score < Control Class_Score

b. Experiment Class_Score > Control Class_Score

c. Experiment Class_Score $=$ Control Class_Score

From the table 2 above about result of wilcoxon signed rank's test we know that the data formed into three classes in wilcoxon theory, they are: Negative Ranks, Positive Ranks, and Ties. The conclusions of the test above as follows:

1. Negative ranks will show how much students on the class experiment are negative score then students on the class control. The result of wilcoxon signed rank's test shows just a one student have negative ranks.

2. Positive ranks will show how much students on the class experiment are positive score then students on the class control. The result of wilcoxon signed rank's test shows there are 31 students has positive ranks. 
3. Ties will show how much students on the class experiment have a same score with the students on the class control. It mean, the students' score of this class are not influenced by the snowing ball method. The result of wilcoxon signed rank's test shows there are 4 students has ties.

Based on the description above, the researcher concludes snowing ball method that used on this research will increase the average students' score by $86 \%$. It mean the snowing ball method on the experiment class is successful to improving the students' vocabolary mastery.

The wilcoxon signed ranks test is also obtained table as follow:

Table 3. Result of statistic's Test

\begin{tabular}{|l|rr|}
\hline \multicolumn{3}{|c|}{ PostTest_Score - PreTest_Score } \\
\hline$Z$ & $-4.900^{\mathrm{b}}$ \\
Asymp. Sig. (2-tailed) & & .000 \\
\hline
\end{tabular}

a. Wilcoxon Signed Ranks Test

b. Based on negative ranks.

From the table 3 above about result of statistic's test we know that $Z$ value is $-4,9^{b}$. It mean the experiment class score is more higher then control class score. The table also shows Asymp. Sig. (2-tailed) value is 0,000 . It means there is a significant change in students' average score.

\section{Discussion}

From the result of this research, we know that that the average students in experiment class is higher then average students in control class. It mean the snowing ball's method that used on this research is successful to improve the student's score in English on experiment class and success to improve their vocabolary mastery. The snowing ball method that used on this research will increase the average students' score by $86 \%$. It mean the snowing ball method on the experiment class is successful to improving the students' vocabolary mastery.

The snowing ball method could cover the need for all types of students. The snowing ball give a freedom for students to increase their vocabulary and improving themselves in English. So, we concluded that snowing ball method are more affected to improving students' vocabulary.

The dictionaries could help the students learn new vocabulary, especially the stem-forms. The use of Classroom English and English routines proved to be helpful in the acquisition of English competencies. The students were familiar with it and began to use it. For the long and complex expressions, although the students did not get the exact meaning, they could comprehend the language.The combination of English and Indonesian could help the students to understand the teacher's explaation and instruction. It was also helpful when the teacher used gestures so that the students could get the better understanding in the teacher's explanation and instruction. The vocabulary affects the communication process. It affects the will and the ability to express ideas correctly. 


\section{CONCLUSION}

The Conclusion of this research about Improving Students' Vocabulary though Snowing Ball as follows:

1. The average students in experiment class is higher then average students in control class. It mean the snowing ball's method that used on this research is successful to improve the student's score in English on experiment class and success to improve their vocabolary mastery.

2. The snowing ball method that used on this research will increase the average students' score by $86 \%$. It mean the snowing ball method on the control class is successful to improving the students' vocabolary mastery.

3. The snowing ball method could cover the need for all types of students. The snowing ball give a freedom for students to increase their vocabulary and improving themselves in English. So, we concluded that snowing ball method are more affected to improving students' vocabulary on grade VII/C.

4. The dictionaries could help the students learn new vocabulary, especially the stemforms.

5. The use of Classroom English and English routines proved to be helpful in the acquisition of English competencies. The students were familiar with it and began to use it. For the long and complex expressions, although the students did not get the exact meaning, they could comprehend the language.

6. The combination of English and Indonesian could help the students to understand the teacher's explaation and instruction. It was also helpful when the teacher used gestures so that the students could get the better understanding in the teacher's explanation and instruction.

The vocabulary affects the communication process. It affects the will and the ability to express ideas correctly.

\section{ACKNOWLEDGMENTS}

Alhamdulillahi robbil 'alamin, the researcher expressed his highest gratitude to Allah Subhanahu wa ta'ala for his blessings, love, opportunity, health, and mercy to finish this article. I also greateful to Dr. H Odo Fadloeli, MA, who has guided my article patiently, thanks to colleagues who have also provided support.

\section{REFERENCES}

Beck, I. L., McKeown, M. G., \& Kucan, L. (2018). Bringing Words to Life: Obust Vocabulary Instruction. New York: Guilford.

Brown, H. D. (2019). The Analysis of Principles of Language Learning and Teaching. Journal of Englewood Cliffs, 1(1), 12-27.

Burns, A. (2018). Collaborative Action Research for English Language Teachers. Journal of Cambridge University, 1(3), 136-151.

Cameron, L. (2019). Teaching Language to Young Learners. Journal of Cambridge University, 1(4), 204-219.

Echevaria, J. (2018). Making Content Comprehensible for English Langeage Learners. Journal of Allyn University, 1(5), 240-255.

Haerunisa, E. (2019). Some Constraits in the English Teaching Learning Process at SD Terban Taman I. Universitas Negeri Yogyakarta.

Harmer, J. (2018). The Practice of English Language Teaching. Journal of Pearson Education 
Ltd, 2(1), 1-15.

Hughes, S. (2019). A Handbook of Classroom English. Journal of Oxford University Press, 2(2), 32-46.

Johnson, E. B. (2019). Contextual Teaching and Learning (XVII). California: Corwin Press.

Kindsvatter, R. S., Willen, W., \& Ishler, M. (2019). Dynamics of Effective teaching. (M. P. and Copying, Ed.) (XXIII). New York: Longman Publisher.

Larcom, D. (2019). English is Fun: Puzzles and Word Study for Mid to High Level Students. Journal University of Malang, 3(1), 1-13.

Madya, S. (2019). Competencies Required of Foreign Language Teachers. Journal of Yogyakarta State University, 3(2), 28-41.

McKeown, M. G. (2019). Teaching by Principles: The Analysis of Interactive Approach to Language Pedagogy. Journal of Longman Inc, 1(2), 56-67.

Parmawati, A. (2018). Using Magic Sentences Technique to Improve Students'vocabulary. Lingual: Journal of Language and Culture, 6(2), 28-28.

Rahman. (2018). Learning Methods: The Snow Ball Throwing. Beijing: Beijing Publishing Group.

Sugiyono. (2013). Metodelogi Penelitian Kuantitatif, Kualitatif dan R\&D. Bandung: Alfabeta.

Sugiyono. (2016). Metode Penelitian Pendidikan (Pendekatan Kuantitatif, Kualitatif, dan $R \& D)$. Bandung: Alfabeta. 